\title{
Properties of different bast fibres in two retting methods
}

\author{
SAPNA PATHAK AND SHAHNAJ JAHAN
}

Received: 05.08.2015; Revised: 03.04.2016; Accepted: 17.04.2016

See end of the paper for authors' affiliations

\section{SAPNA PATHAK}

Department of Clothing and

Textiles, College of Home Science, G.B. Pant University of Agriculture and Technology, Pantnagar, U.S. NAGAR (UTTARAKHAND) INDIA Email : sapnavibhav@gmail.com
ABSTRACT : India is primarily agricultural country. The various plants grow widely due to favorable agro climatic conditions. These plants are considered as waste and are not frequently used in the field of textiles due lack of familiarity. Proper utilization of these indigenous plant resources can provide a good opportunity of employment and income generation to the rural peoples. The stems of five different plants i.e. semal (Bombax ceiba), tesu (Butea monosperma), lasora (Cordial dichotoma), lantana (Camellia sinensis) and phalsa (Grewia subequinails) were kept in the stagnant water for water retting and treated with sodium hydroxide in chemical retting. Water retting is biological fermentation process which produces biodegradable wastes. This enhances the soil nutrients without harming the environment. Chemical retting deteriorated the fibre quality as well as more polluted water were produced which deteriorated the ecosystem.

KEY WORDS: Agro-climatic, Textiles, Employment, Nutrients, Ecosystem

- HOW TO CITE THIS PAPER : Pathak, Sapna and Jahan, Shahnaj (2016). Properties of different bast fibres in two retting methods. Asian J. Home Sci., 11 (1) : 58-61, DOI: 10.15740/HAS/AJHS/11.1/58-61. 